\title{
Does Audit Fees and Non-Audit Fees Matters in Audit Quality?
}

\section{Yuvaraj Ganesan, Ranjani Narayanan1, Hasnah Haron², and Anwar Allah Pitchay ${ }^{3}$}

${ }^{1}$ Graduate School of Business, Universiti Sains Malaysia, 11800 Penang, Malaysia

${ }^{2}$ Faculty of Industrial Management, Universiti Malaysia Pahang, Lebuhraya Tun Razak, 26300 Gambang, Pahang, Malaysia

${ }^{3}$ School of Management, Universiti Sains Malaysia, 11800 Penang, Malaysia

\section{Abstract}

The purpose of this paper is to examine the influence of audit fees and non-audit fees on audit quality of the Public Listed Companies in Malaysia. The research is timely as recently, and many business cases have been exploded after an unqualified audit report issued on the financial statement of the company. The quantitative research approach and secondary data utilized for this study. Further, this study employs a cross-sectional which the data collected from 201 listed company on Bursa Malaysia

Corresponding Author:

Yuvaraj Ganesan

yuvaraj@usm.my

Received: 5 August 2019

Accepted: 14 August 2019

Published: 18 August 2019

Publishing services provided by

Knowledge E

(c) Yuvaraj Ganesan et al. This article is distributed under the terms of the

Attribution License, which

permits unrestricted use and redistribution provided that the original author and source are credited.

Selection and Peer-review under the responsibility of the FGIC2019 Conference Committee.

\section{G OPEN ACCESS} for the financial year ending in 2017. The results reveal that non-audit fees (NAF) and audit fees (AF) have influenced the audit quality (AQ). The finding of this study conducive to auditing literature by enhancing the knowledge of audit scholars and able to assist policy maker such as the Malaysia Institute of Accountants (MIA) in developing new strategy or policies that can enhance the $A Q$.

Keywords: audit quality, fees, audit firm, non-audit services.

\section{Introduction}

It is well known that financial statements of the listed company in most of the countries need to be audited by an independent auditor from the audit firm as required by the law. The audited financial statement is important for the stakeholders such as shareholders, creditors, governments, employees, and others to verify or confirm the financial health and going concern of the company. However, the issue of Audit Quality (AQ) becomes a debating nowadays as more fraud scandal of the company has exploded after issued a clean audit report. $A Q$ is to determine the level of assurance the audit firm obtained with satisfactory data that the financial reporting truly reflecting the company's economics status (Gaynor, Kelton, Mercer, \& Yohn, 2016; Yurisandi \& Puspitasari, 2015). According to DeAngelo (1981), it is a responsibility of the external auditors to define the $A Q$ by highlighting the breach in the customer's accounting system when there is a discrepancy 
or inconsistency during the audit process. Hence, continues improvement on the $A Q$ to achieve a reliable audited financial report is being the primary concern of most of the audit firms in providing an efficient audit service as well as capable of determining if there is any financial reporting fraudulent, which is becoming a major white-collar crime (Gottschalk \& Gunnesdal, 2018). For examples, retailer BHS case in the UK, where the PricewaterhouseCoopers (PwC) has been fined $£ 6.5$ million pounds by UK Financial Reporting council as the auditor failed to give consideration potential red flags or risk on the ability of the BHS continue business or going concerns as the Company collapsed days after the audit completed. Further, the audit partner has been fined with $£ 325,000$ pounds and banned from auditing services for 15 years. In this case, also FRC found that non-audit fees charged by PwC to the group of the company are eight times more than its audit fees (Jones \& Ridley, 2018). Meanwhile, in a developing country, the latest case is 1 Malaysia Development Berhad (1MDB) which placed Malaysia in a stage of disgrace in the eye of business and auditing world. In the 1MDB scandal, two big four audit firm (KMPG and Deloitte) audited the financial report for the year ending March 2010 until 2014, which have issued clean auditor reports. However, currently, all the auditor reports for $1 \mathrm{MDB}$ is not valid as both auditors withdrew the assurance given for the audited financial statements and make a called to be public that their audit report which previously issued should not be relied upon. Further, the Malaysian Securities Commission has reprimanded and fined Deloitte firm around US $\$ 535,000$ for failure to discharge its statutory obligations and also failed to produce qualified auditor reports (Sukumaran, 2019). Besides that, the global corporate scandals or corporate failure in a few countries has raised valuable questions about the quality of auditing and the credibility of the auditor (Kaklar, Kangarlouei, \& Motavassel, 2012).

Even though, auditing services are fully regulated but still have the issues raising about the audit quality. There are many factors that caused this issue. One reason may be the audit fees charges are not able to provide quality auditing as it is unable to cover the costs of proper auditing or the non-audit fee charges are only tools to eliminate the audit procedures. As highlighted in the case of BSH whereby the partner only spent two hours to review the audit work and issue an unqualified report. The audit fees and nonaudit fees have been debated nearly two decades ago. There are two views of argument about providing audit and non-audit services (NAS) by the same auditor. The first view is that by providing both services to the same company, the auditor independent will be compromised. This is due to the economics relationship builds between the auditor and the management during providing NAS. The auditor can influence the company's decision in several matter as their role has changed from an independent outsider to 
become an inside adviser. The auditors' judgment can also be influenced as an auditor are taking several roles through NAS for the same company. Meanwhile, the second view is more towards the positive side, the auditor who provided both services to the same company will have knowledge spillover where the auditor can conduct the audit more effectively and efficiently (Abdul Wahab, Gist, \& Nik Abdul Majid, 2014).

Although there are previous studies on $A Q$ conducted in many countries with different factors influencing the $A Q$, but most of the study fails to investigate the impact of audit fees and non-audit fees on $A Q$ in one study. Hence, this research is conducted to examine the impact of fees paid to the audit firm in term of audit and non-audit services on AQ. This study will enhance scholar knowledge and fill up the research gap. Audited financial statements are crucial; it gives vital information for financial report users. These users may include potential and current investors, stake takers, and those who need trustworthy financial information before making any critical decisions. This study also will assist the governing bodies such as the Malaysian Institute of Accountants (MIA) and relevant policymakers.

In the upcoming sections, the literature review and hypothesis of the study will be discussed. Next, the research methodology and measurement will be addressed. Finally, the findings of the study will be discussed and conclude with the implications of this study.

\section{Literature Review and Hypothesis Development}

\subsection{Audit Quality}

Experts usually define $A Q$ as the auditor's capability to meet the legal and professional desires. In other words, $A Q$ is also known as the audit firm experience and professionalism as well as practical knowledge of understanding their client's business operations (Corbella, Florio, Gotti, \& Mastrolia, 2015). In light of this explanation, AQ also can be said as unpredictable. The quality of the audit can be considered poor if an auditor has failed to fulfill the professional and legal requests. If the $A Q$ is high, it conveys audit reporting are filled with useful information, but if the $A Q$ is low, then the modification of the audit report would have very minimal or no informational value to the users such as management, or shareholders and investors (Francis, 2011). Many studies based on the $A Q$ have an essential assumption that most audit firms able to meet the minimum legal professional requirements and able to identify the financial reporting fraud or misstatement (Francis, 2004). Therefore, it is anticipated that high AQ 
can be a tool to prevent the financial crisis and fraudulent (Kaawaase, Assad, Kitindi, \& Nkundabanyanga, 2016).

\subsection{Audit Fee and Audit quality}

The earliest study conducted by Palmrose (1986) shows that the audit firm is charging higher fees for a better AQ. Meanwhile, another research has an extended view of the Palmrose (1986) study. It stated that in order not lose their profitable client, auditor tries not to be harsh towards their client (Hoitash, Markelevich, \& Barragato, 2007). As per the research by Huang, Chang, and Chiou (2015) demonstrates that greater audit fees in market concentration will be improved indirectly the $A Q$. In Malaysia very few credible research that gives the evidence on the role of audit fees in relation to $A Q$ compared to research done by the overseas counterparts. In addition, Yatim, Kent, and Clarkson (2006) stress that the higher the audit quality required by the institutional investor, the higher the audit fee. With the rise of the agency problem, management needs for a higher quality audit to solve the discrepancy. Hence, it is hypothesized that:

$\mathrm{H} 1$ : There is a positive relationship between audit fee and audit quality

\subsection{Non-Audit fee and Audit Quality}

Past literature reveals that the influence of non-audit fee on $A Q$ is unclear. The provision of the non- audit services (NAS) such as advisory on tax services, tax planning, the recommendation of designing and implementing the financial IT structure and other mandatory financial services by the external auditors (Bell, Causholli, \& Knechel, 2015; Tepalagul \& Lin, 2015). Past studies highlighted that the auditor was gained by providing the NAS as they are able to further understand of the auditee business and enhance the auditor's knowledge which will lead to increase the AQ (Lennox, 1999). Additionally, a study in Sweden by Svanström (2013) found that NAS has a positive influence on $A Q$. Further, the author clarified that the combined provide audit and NAS to the same customer able occurrence of the knowledge spillover among the services rather than impaired independence of the auditor. In contrast, Kinney \& Libby (2002) mentioned, "more deceptive effects on the economic pledge may result from unexpected non-audit service fees which able to encourage for attempted bribes." Based on the argument regards the auditors and non-audit fees, it is believed that auditor will need to think a way of securing the business with the client for future prospect. Therefore, the auditor will find a way of conducting an audit on the surface, and services will have the influence 
of prejudice. The auditor is bound to conduct an audit in a simple manner so that the results will favor the customer. This statement is supported by Bamahros, Wan-Hussin, and Abdullah (2015) revealing that if the auditor does not conform to the expectation of the client and client who found a discrepancy with agency problems will have the tendency of reduction of NAS obtained from the auditor. Thus, we test the following hypothesis:

$\mathrm{H} 2$ : There is a positive relationship between non-audit fee and audit quality

\section{Methodology}

In this study, a quantitative method utilized and the unit of analysis are an organizational level. The Public listed companies were selected as the subject of the study as they tend to have more accurate and comprehensive annual reports besides the information can be used as the secondary data. All the required information can be easily obtained from the annual reports of Public Listed companies' which able to download from the Bursa Malaysia website as it is publicly available comparing to non-listed companies. The population of the study was chosen based on non-financial firms as per Bursa Malaysia report is in a total of 674 companies (Bursa, 2019). However, the sample size consists of 201 companies from eleven sectors of non-financial sectors were chosen by used stratified random sampling. The data of the selected companies were obtained from their 2017 audited annual reports, and this data is used to access the variable for audit fees, non-audit fees, and AQ. Smart PLS-SEM is used in this study to test the relationship between the variables.

The $A Q$ is measured through the abnormal working capital accruals (AWCA) as calculated in DeFond and Zhang (2014); Fredriksson, Kiran, and Niemi (2018). The proxy for $A Q$ estimates that AWCA as the variance between actual WC for the current year and the level of WC which is predicted for previous year's WC to the sales ratio for each company year. AWCA is calculated as follows:

$$
A W C A_{i, t}=W C_{i, t}-\left[\left(\frac{W C_{i, t-1}}{S_{i, t-1}}\right) \times S_{i, t}\right]
$$

Where; AWCA = Abnormal working capital accruals for the company I in time $t$

WC = Noncash working capital accrual computed as (current assets - cash and short term investment) - (current liabilities - short term loans) for the company $i$ in time $t$

$\mathrm{S}=$ Total number of sales to customer form company $\mathrm{i}$ at time $\mathrm{t}$ or $(\mathrm{t}-\mathrm{i})$

This measure is used to find the absolute value of AWCA as a proxy for AQ. Meanwhile, the independent variables which are non-audit fees measured via the natural 
log of non-audit fees and AF are measured by the natural log of audit fees paid by the company to their auditor (Christ, Masli, Sharp, \& Wood, 2015). Additionally, two control variables included in this study are profitability, which measured through return on assets (Dahmash, 2015) and firm size measured by the natural log of revenue (Dang, Li, \& Yang, 2018).

\section{Results}

In this study, the multicollinearity is not a problem as the values of VIF are less than 5 as recommended (Hair Jr, Hult, Ringle, \& Sarstedt, 2016). The study model can explain 13.6 percent of the variance in independent variables on audit quality. Also, the model has predictive relevance as the value of $Q^{2}$ above zero, as shown in table 1 .

Bootstrapping function whereby the threshold used is based on the one-tailed test for a direct approach. Based on the result, $\mathrm{H} 1$ indicates the audit fee is positively significant at $p<0.01$ towards $A Q$ (standard beta $=0.328$, t-value $=3.580$ ). Hence, $\mathrm{H} 1$ is supported. Meanwhile, $\mathrm{H} 2$ is to examine the non-audit fee influence on $A Q$. The result showed that unable to reject $\mathrm{H} 2$ as the non-audit fees have been positively significant with $A Q$ at $p$ $<0.01$ (standard beta $=0.075, \mathrm{t}$-value $=2.910$ ). As expected, both of hypothesizes are supported. These results are illustrated in Table 1 and Figure 1 and 2.

TABLE 1: Hypothesis Testing.

\begin{tabular}{l|c|c|c|c|c|c|c|c|c|}
\hline Hypotheses & Relationship & $\begin{array}{c}\text { Std. Beta } \\
(\beta)\end{array}$ & $\begin{array}{c}\text { Std. } \\
\text { Error }\end{array}$ & t-value & P-value & Decision & $R^{2}$ & $Q^{2}$ \\
\hline$H 1$ & AF $->A Q$ & 0.328 & 0.092 & $3.580^{*}$ & 0.000 & Supported & 0.136 & 0.113 \\
\hline H2 & NAF $->A Q$ & 0.075 & 0.026 & $2.910^{*}$ & 0.002 & Supported & \\
\hline
\end{tabular}

Notes: significant level at 1-tailed ${ }^{*} \mathrm{p}<0.01$,

\section{Discussion and Conclusion}

The finding of the study proved that the audit fee has a positive relationship with $A Q$. This is consistent with the argument by Hoitash et al. (2007) which reveals that audit firm charges higher audit fees will perform auditing with good quality as they scared of losing a profitable customer if provide lower audit quality. In other words, the finding can be interpreted that higher audit fee paid will receive a higher $A Q$; otherwise, the companies will give more financial pressure and problem to the audit firm to perform better AQ as the audit fees are highly paid (Ghafran \& O'Sullivan, 2017). On other hands, as predicted, the results depict that non-audit fee able to influence the audit quality 


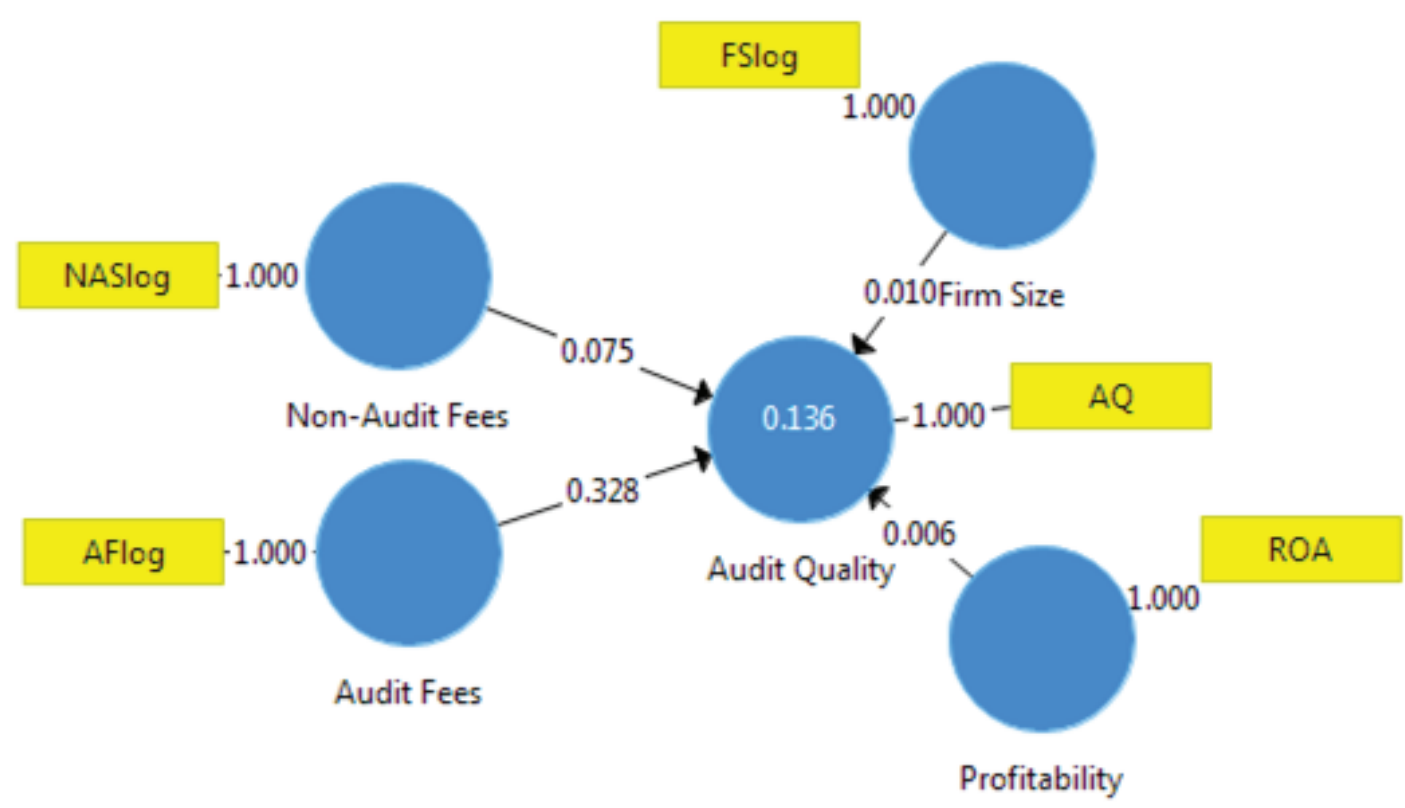

Figure 1: PLS Structured Model for Path Coefficients.

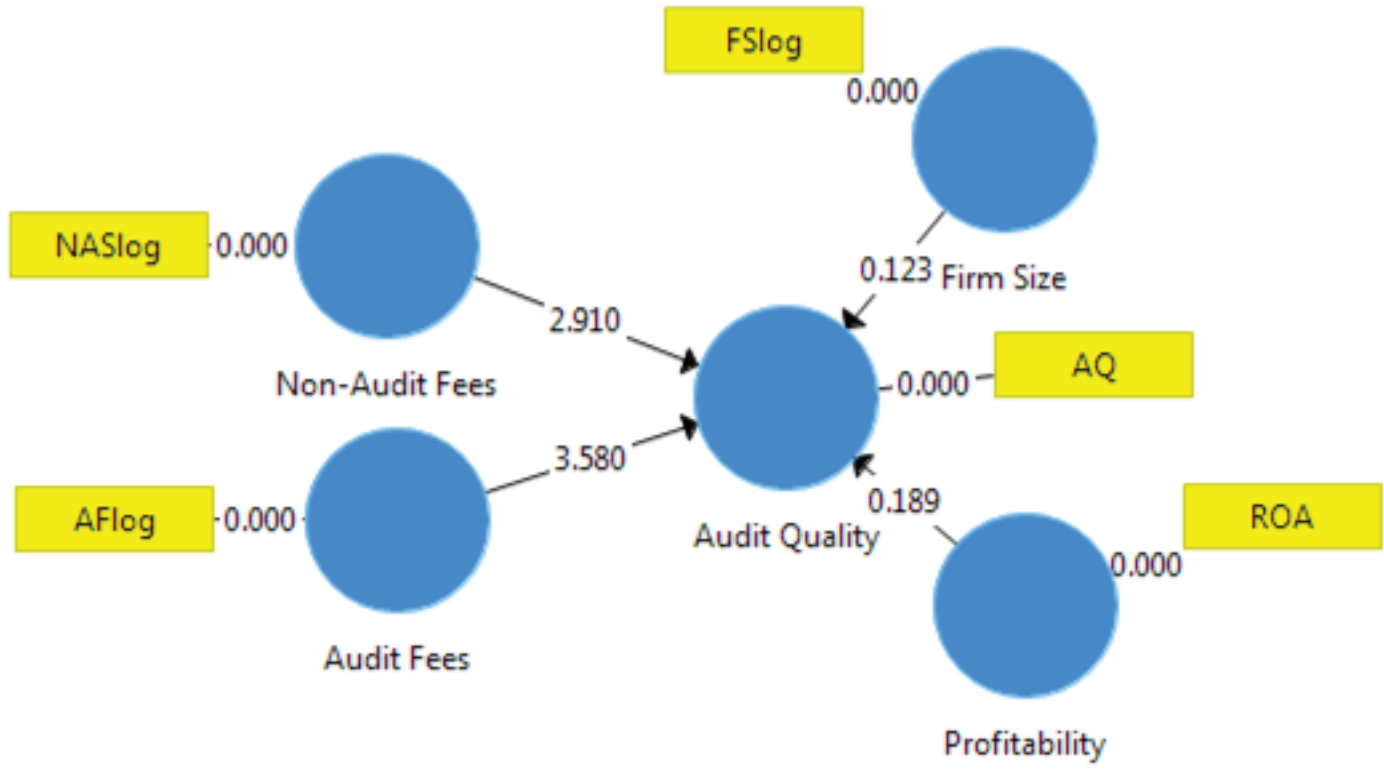

Figure 2: PLS Structured Model for T values.

as the auditor obtained the knowledge spillover when providing NAS and utilized the knowledge when rendering auditing service. This finding in line with Svanström (2013).

The theoretical implications from this study fill up the gaps in the literature and enable to enhance the knowledge of the scholar on the relationship between fees paid to the auditor in terms of audit and NAS fees and audit quality. Besides, the practical contribution is the findings provide significant implications for the audit firms to strategy's plans for improving the audit quality of their firm through the audit fees and non-audit 
services they provide to the client. On the other hand, this study can help Malaysian Institute of Accountant (MIA) to improve their policies and regulations by developing technical competence, fee's regulations and work performance, which helps audit firm to improve their audit quality. The results should caution to generalize in other years as this study conducted as a cross-sectional design in which the data was obtained from annual report 2017. Therefore, future research needs to adopt longitude study or panel data analysis.

Globally, it has become prevalent for the audit firms and company's management as well as a stakeholder to debate on the audit quality due to the increasing number of a financial scandal, which is a significant threat to the existence and efficiency of capital markets and reputation of the audit profession. The objective of this study was to examine the influence of audit and NAS fees on AQ for the non-financial Public Listed companies in Malaysia. As a conclusion, the results confirm that the audit fees and nonaudit fees are found to have a significant relationship with audit quality. Furthermore, the provision of NAS able to enhance the spillover knowledge to the auditor, as a result, showed that non-audit fee has a positive effect on audit quality.

\section{Funding}

We would like to thank Universiti Sains Malaysia for the financial assistance through research grants with 304.PPAMC.6316433

\section{References}

[1] Abdul Wahab, E. A., Gist, W. E., \& Nik Abdul Majid, W. Z. (2014). Characteristics of non-audit services and financial restatements in Malaysia. Journal of Contemporary Accounting \& Economics, 10(3), 225-247. doi: 10.1016/j.jcae.2014.10.001

[2] Bamahros, H. M., Wan-Hussin, W. N., \& Abdullah, Â. (2015). Non-audit services, audit firm tenure and earnings management in Malaysia. Asian Academy of Management Journal of Accounting and Finance, 11(1), 145-168.

[3] Bell, T. B., Causholli, M., \& Knechel, W. R. (2015). Audit firm tenure, non-audit services, and internal assessments of audit quality. Journal of Accounting Research, 53(3), 461-509.

[4] Bursa. (2019). from http://www.bursamalaysia.com/market/listed-companies/list-ofcompanies/main-market/ 
[5] Christ, M. H., Masli, A., Sharp, N. Y., \& Wood, D. A. (2015). Rotational internal audit programs and financial reporting quality: Do compensating controls help? Accounting, Organizations and Society, 44, 37-59.

[6] Corbella, S., Florio, C., Gotti, G., \& Mastrolia, S. A. (2015). Audit firm rotation, audit fees and audit quality: The experience of Italian public companies. Journal of International Accounting, Auditing and Taxation, 25, 46-66. doi: 10.1016/j.intaccaudtax.2015.10.003

[7] Dahmash, F. N. (2015). Size effect on company profitability: Evidence from Jordan. International Journal of Business and Management, 10(2), 58.

[8] Dang, C., Li, Z. F., \& Yang, C. (2018). Measuring firm size in empirical corporate finance. Journal of Banking \& Finance, 86, 159-176.

[9] DeAngelo, L. E. (1981). Auditor size and audit quality. Journal of accounting and economics, 3(3), 183-199.

[10] DeFond, M., \& Zhang, J. (2014). A review of archival auditing research. Journal of accounting and economics, 58(2-3), 275-326.

[11] Francis, J. R. (2004). What do we know about audit quality? The British accounting review, 36(4), 345-368.

[12] Francis, J. R. (2011). A framework for understanding and researching audit quality. Auditing: A Journal of Practice \& Theory, 30(2), 125-152.

[13] Fredriksson, A., Kiran, A., \& Niemi, L. (2018). Reputation Capital of Directorships and Audit Quality.

[14] Gaynor, L. M., Kelton, A. S., Mercer, M., \& Yohn, T. L. (2016). Understanding the relation between financial reporting quality and audit quality. Auditing: $A$ Journal of Practice \& Theory, 35(4), 1-22.

[15] Ghafran, C., \& O'Sullivan, N. (2017). The impact of audit committee expertise on audit quality: Evidence from UK audit fees. The British Accounting Review, 49(6), 578-593.

[16] Gottschalk, P., \& Gunnesdal, L. (2018). White-Collar Crime Detection White-Collar Crime in the Shadow Economy (pp. 111-134): Springer.

[17] Hair Jr, J. F., Hult, G. T. M., Ringle, C., \& Sarstedt, M. (2016). A primer on partial least squares structural equation modeling (PLS-SEM): Sage publications.

[18] Hoitash, R., Markelevich, A., \& Barragato, C. A. (2007). Auditor fees and audit quality. Managerial Auditing Journal, 22(8), 761.

[19] Huang, T.-C., Chang, H., \& Chiou, J.-R. (2015). Audit market concentration, audit fees, and audit quality: Evidence from China. AUDITING: A Journal of Practice \& Theory, 35(2), 121-145. 
[20] Jones, H., \& Ridley, K. (2018). PwC failed to flag BHS risks ahead of retailer's collapse: regulator. Retrieved June 1, 2019, from The Thomson Reuters. https://www.reuters.com/article/us-bhs-accounts-regulator/pwc-failed-toflag-bhs-risks-ahead-of-retailers-collapse-regulator-idUSKBN1L011L

[21] Kaawaase, T. K., Assad, M. J., Kitindi, E. G., \& Nkundabanyanga, S. K. (2016). Audit quality differences amongst audit firms in a developing economy: The case of Uganda. Journal of Accounting in Emerging Economies, 6(3), 269-290.

[22] Kaklar, H. M., Kangarlouei, S. J., \& Motavassel, M. (2012). Audit quality and financial reporting quality: case of Tehran Stock Exchange (TSE). Innovative Journal of Business and Management, 1(03).

[23] Lennox, C. S. (1999). Non-audit fees, disclosure and audit quality. European accounting review, 8(2), 239-252.

[24] Palmrose, Z.-V. (1986). Audit fees and auditor size: Further evidence. Journal of Accounting Research, 97-110.

[25] Sukumaran, T. (2019, 30/Jan/2019). Malaysia fines auditor Deloitte US $\$ 535,000$ for 1MDB breaches. South China Morning Post. Retrieved from https: //www.scmp.com/news/asia/southeast-asia/article/2184302/malaysia-fines-auditfirm-deloitte-serious-breaches-linked

[26] Svanström, T. (2013). Non-audit Services and Audit Quality: Evidence from Private Firms. European Accounting Review, 22(2), 337-366. doi: 10.1080/09638180.2012.706398

[27] Tepalagul, N., \& Lin, L. (2015). Auditor independence and audit quality: A literature review. Journal of Accounting, Auditing \& Finance, 30(1), 101-121.

[28] Yatim, P., Kent, P., \& Clarkson, P. (2006). Governance structures, ethnicity, and audit fees of Malaysian listed firms. Managerial Auditing Journal, 21(7), 757-782.

[29] Yurisandi, T., \& Puspitasari, E. (2015). Financial Reporting Quality-Before and After IFRS Adoption Using NiCE Qualitative Characteristics Measurement. Procedia-Social and Behavioral Sciences, 211, 644-652. 